\title{
Feasibility Evaluation of Wastewater Treatment Plant System: A Case Study of Domestic Wastewater System in Sleman Regency, Yogyakarta, Indonesia
}

\author{
Sri Puji Saraswati ${ }^{1 *}$, Gregorius Henry Diavid ${ }^{2}$, Sophia An Nisa ${ }^{3}$, Nilna Amal ${ }^{4}$, \\ Visi Asriningtyas ${ }^{5}$ \\ 1Department of Civil and Environmental Engineering, Faculty of Engineering, Universitas Gadjah Mada, \\ Jl. Grafika Kampus No. 2, Sleman, DI Yogyakarta, INDONESIA \\ ${ }^{2}$ Self Employed in Environmental Engineering, \\ Medari Gede IV RT 004 RW 011, Caturharjo, Sleman, DI Yogyakarta, INDONESIA \\ ${ }^{3}$ Environmental Engineer Freelancer, \\ Jl. Sukaresmi no. 19 Dago Giri, Lembang, Bandung Barat, INDONESIA \\ ${ }^{4}$ Water Laboratory, Faculty of Engineering, Universitas Lambung Mangkurat, \\ Jl. A. Yani Km 36.5 Banjarbaru, Kalimantan Selatan, INDONESIA \\ ${ }^{5}$ Home Education Jogja, \\ Jl. Tongkol Raya no.17, Minomartani, Sleman, DI Yogyakarta, INDONESIA \\ *Corresponding authors: spswatinz@ugm.ac.id
}

SUBMITTED 15 March 2021 REVISED 20 May 2021 ACCEPTED 31 May 2021

\begin{abstract}
Domestic Wastewater Treatment Plant (DWWTP) type 1 and DWWTP type 2 were being evaluated. DWWTP type 1 is located in Sembir area while DWWTP type 2 is located in Tambakrejo area which are both in Sleman Regency, Special Region of Yogyakarta (Daerah Istimewa Yogyakarta or DIY), Indonesia. The emphasis of this research is to choose the manhole material which has the least leakage to the soil, influent discharge performance and wastewater treatment quality effluent. The method used to measure the discharge was by averaging daily discharge for twelve hours, while the $E$. Coli bacteria under the manhole was also being analyzed. Pollution Index method was also used to evaluate the pollution levels of the wastewater treatment effluent. Results of the study indicated that DWWTP type 1 performance was not optimal because the number of users was greater than that of the design. The impacts were excessive capacity, improper detention time and several parameters of the effluent did not meet the Indonesian legal regulation, including Chemical Oxygen Demand (COD), with efficiency of $34.43 \%$. Wastewater treatment quality effluent parameters which met the Indonesian legal regulation were $\mathrm{pH}$, TSS, TDS, Oil and Grease and Chlorine for DWWTP type 1. Pollution Index (PI) of DWWTP type 1 was 7.02 and PI of DWWTP type 2 was 6.96 which were relatively categorized as moderately polluted. DWWTP type 2 performance was optimal with mean discharge lower than the design discharge. Parameters of the effluent which met the Indonesian legal regulation were pH, TSS, TDS, Oil and Grease, Detergent and COD for DWWTP type 2. The COD of DWWTP type 2 met the Indonesian legal regulation with high efficiency of $73.24 \%$. The E. Coli bacteria was not found in soils under the ring type precast concrete manholes. Hence ring type precast concrete base manhole is recommended.
\end{abstract}

KEYWORDS Domestic wastewater treatment plant; Wastewater treatment quality effluent; Manhole; Pollution Index; Detention time

(c) The Author(s) 2021. This article is distributed under a Creative Commons Attribution-ShareAlike 4.0 International license.

\section{INTRODUCTION}

There is a need to evaluate the effluent of domestic wastewater system since groundwater and river in some part of Merapi Aquifer, Sleman Regency, Daerah Istimewa Yogyakarta (DIY), is polluted. Asriningtyas \& Putra (2006) has simulated the whole Merapi Aquifer with emphasis in Sleman Regency and Satapona et al. (2018) in Malioboro Yogyakarta with the findings that productive aquifer system tended to decrease in water level with the rate of groundwater withdrawal that was in accordance with the increase of population, business and tourist growth rate in the area. However, the opposite effect, that was the rising of groundwater level was prevalent (Manny et al., 2016) when there was urban recharge and 
sewers leakage. The rivers at the vicinity of the research area were also polluted based on water quality index analysis including significant parameters of Chemical Oxygen Demand (COD) and Total Coliforms (Saraswati et al., 2019). The process of leaching was different in different types of soils (Meynendonckx et al., 2006). Leaching of E.Coli bacteria from the household blackwater and greywater pipes at manholes were being evaluated to see which material is best practice in field between precast concrete and masonry. Two other materials which were ring type precast concrete and cast in-situ concrete from other communities in Sleman Regency were also being analyzed in comparison to the manhole materials of the research area. The lined sections of the grout lined channels were not always impervious; thus safety considerations of the lining works were paramount to help avoiding notable hazards (Hibbs et al., 2016).

Full-scale anaerobic reactors of communal Decentralized Wastewater System (DEWATS) which were implemented in some parts of tropical regions in order to consolidate the basis of future design and support monitoring, operation and maintenance procedures as well as biogas production measurements has been researched (Reynaud, 2014). Main constituents of biogas are methane and carbon dioxide (Ilukor, 1986); other gases are carbon monoxide, nitrogen, water vapor, hydrogen and hydrogen sulphides. The biogas production increased with the addition of $6 \%$ bran at the process of wastewater treatment using artificial sludge (Nisa, 2015) and the wastewater removal efficiency was good for the TDS (Total Dissolved Solids), EC (Electric Conductivity), BOD (Biochemical Oxygen Demand), COD and Nitrate. Susanthi et al. (2018) has also proposed a continued maintenance with pumping the faeces from the biodigester at least in every two years.

There are many problems in dense, rapidly urbanizing cities, including shared sanitation with poor management (Foggitt et al., 2019); yet in Sleman, Indonesia the condition is better with less shared sanitation although the capacity of septic tank should be in a caution prior to the design due to excess of population of the residence in the near future. The evaluation of wastewater treatment plant system in this research is to accommodate the government operation, maintenance, and monitoring objectives to obtain future recommendation for a better wastewater treatment system in Sleman Regency, DIY, Indonesia.

\section{MATERIAL AND METHOD}

\subsection{Domestic Wastewater System within the Area of Research}

The research was located in Sleman, DIY, Indonesia. The precise coordinates are shown in Table 1. Domestic wastewater discharge is originated from the households in one community area which are conveyed through pipes passing through manholes and collected in the treatment plant which is then named Domestic Wastewater Treatment Plant (DWWTP). Intake flowrate $(Q)$ at the inlet of DWWTP in this research is stated as influent discharge with the dimension of $\mathrm{L}^{3} / \mathrm{T}$, while the outlet is defined as the effluent.

Table 1. The Coordinates of the Research Location

\begin{tabular}{lll}
\hline Location & South Latitude & East Longitude \\
\hline $\begin{array}{l}\text { DWWTP type } \\
\text { 1(Sembir) }\end{array}$ & $7^{\circ} 47^{\prime} 40^{\prime \prime} \mathrm{S}$ & $110^{\circ} 29^{\prime} 46^{\prime} \mathrm{E}$ \\
M1S1 & $7^{\circ} 47^{\prime} 34^{\prime \prime} \mathrm{S}$ & $110^{\circ} 29^{\prime} 43^{\prime \prime} \mathrm{E}$ \\
M1S2 & $7^{\circ} 47^{\prime} 32^{\prime \prime} \mathrm{S}$ & $10^{\circ} 29^{\prime} 42^{\prime \prime} \mathrm{E}$ \\
M1S3 & $7^{\circ} 47^{\prime} 30^{\prime \prime} \mathrm{S}$ & $10^{\circ} 29^{\prime} 43^{\prime \prime} \mathrm{E}$ \\
DWWTP type 2 & $7^{\circ} 41^{\prime} 19^{\prime \prime} \mathrm{S}$ & $110^{\circ} 18^{\prime} 15^{\prime} \mathrm{E}$ \\
(Tambakrejo) & & \\
M2S1 & $7^{\circ} 42^{\prime} 51^{\prime \prime} \mathrm{S}$ & $110^{\circ} 22^{\prime} 32^{\prime \prime} \mathrm{E}$ \\
M2S2 & $7^{\circ} 42^{\prime} 50^{\prime \prime} \mathrm{S}$ & $110^{\circ} 22^{\prime} 33^{\prime \prime} \mathrm{E}$ \\
M2S3 & $7^{\circ} 42^{\prime} 48^{\prime \prime} \mathrm{S}$ & $110^{\circ} 22^{\prime} 33^{\prime} \mathrm{E}$ \\
\hline
\end{tabular}

M1S1, M1S2, M1S3 are manholes connected to pipes which flow into DWWTP type 1 while M2S1, M2S2 and M2S3 are manholes connected to pipes which flow into DWWTP type 2 .

The population serviced by the DWWTP type 1 was planned to be 450 inhabitants with 90 litre per day per capita usage of clean water while wastewater was estimated $80 \%$ of the daily clean water consumption. Four hundred inhabitants 
were planned to be served for DWWTP type 2 with clean water consumption of 100 litre per day per capita and wastewater discharge was assumed to be $90 \%$ of clean water consumption. The assumption was based on the Sanimas project and USRI project (Tambakrejo Bersih, 2012; Sembir Asri, 2017; Peraturan Menteri Pekerjaan Umum dan Perumahan Rakyat, 2017) which in the implementation increased because total use of water per capita can be as high as 150 litre per day and wastewater can be as high as 90 litre per day per capita.

The physical construction of DWWTP type 1 which is located in Sembir, Madurejo, Prambanan, Sleman, Yogyakarta at $07^{\circ} 47^{\prime} 40^{\prime \prime}$ south latitude and $110^{\circ} 29^{\prime} 46^{\prime \prime}$ east longitude is shown in Figure 1., collected from Sembir Asri (2017).

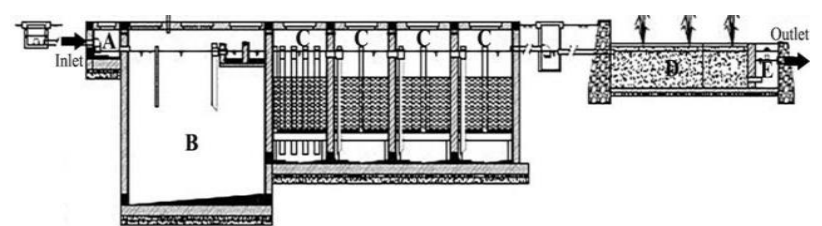

Figure 1. DWWTP type 1 (Source: Sembir Asri, 2017). A is the Equalization tank; $B$ is the Settler; $C$ is the Anaerobic Filter; D is the Horizontal Gravel Filter; $E$ is the Chlorination Chamber.

The physical construction of DWWTP type 2 which is located in Tambakrejo, Sariharjo, Ngaglik, Sleman, Yogyakarta at $07^{\circ} 41^{\prime} 19^{\prime \prime}$ south latitude and $110^{\circ} 18^{\prime} 15^{\prime \prime}$ east longitude is shown in Figure 2., collected from Tambakrejo Bersih (2012).

The equalization tank in this research was a chamber which functioned as a receiver of the domestic wastewater which could be in the form of 2 to 3 compartments with partial partition walls so that it could reduce the flow velocity to halt turbulence of the incoming wastewater and distribute more equal water flow and quality throughout the tank. Settler is a wastewater treatment compartment with the capacity of more than $3 \mathrm{~m}^{3} / \mathrm{d}$, which functioned as sludge stabilizer, yet with low treatment efficiency of around $15 \%$ to $35 \%$ (Sasse, 1998). Therefore, more treatment chambers are needed after the settler. At the DWWTP type 1, it was followed by an AF (Anaerobic Filter) which was a tank composed of several compartments equipped with filters (volcanic boulders, bioballs or other media) to filter the wastewater to provide increased effluent quality prior to the treated wastewater flow to the water body (Sasse, 1998).

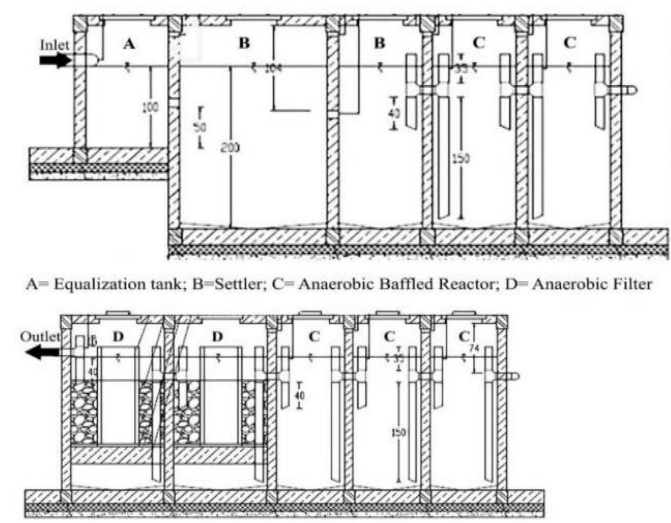

Figure 2. DWWTP type 2 (Source : Tambakrejo Bersih, 2012). $A$ is the Equalization Tank; $B$ is the Settler; $C$ is the Anaerobic Baffled Reactor (ABR); $D$ is the Anaerobic Filter.

In this DWWTP type 1, AF was still continued by HGF (Horizontal Gravel Filter) which was composed of horizontal filter containing round gravels which was suitable for a treatment plant with COD of less than $500 \mathrm{mg} / \mathrm{L}$, which functioned as the last filter before entering the water body (Sasse, 1998). The Chlorination chamber was added to the DWWTP type 1 to kill pathogens and microorganisms with Chlorine, which is a common disinfectant with more dosage compared to chlorination of drinking water because Ammonium and other chemicals in wastewater absorb Chlorine (Saraswati, 1996). At the DWWTP type 2, the settler was continued by Anaerobic Baffled Reactor (ABR) and followed by $\mathrm{AF}$. ABR is functioned as a biologic treatment reactor with stacked sieve to lower the wastewater discharge and to omit gas (Asmadi \& Suharno, 2012). This process is to decompose organic substance with bacteria which does not need oxygen to produce biogas (methane and carbon dioxide), water vapor and a little amount of sludge (Asmadi \& Suharno, 2012). 


\subsection{Manhole}

A manhole for domestic wastewater use is a chamber with a lid on top of it which is used to control wastewater flow from household pipes. The function of the manhole is to know whether wastewater which flow through it has an obstruction as well as a place for maintenance and monitoring wastewater. Manholes are placed at junctions at a distance of 20 meters or less and are also placed at the confluence of pipes with different dimensions or at the change of the pipe slope. Minimal surface area of each manhole is $40 \mathrm{~cm}$ by $40 \mathrm{~cm}$ with variable depth which suited the need of the design. Usually, manholes at house yards have walls which could halt the intrusion of runoff from the rain. Indicator of wastewater quality for health and environment was used for soils below the manholes in accordance with Permenkes No. 32 Tahun 2017 (Peraturan Menteri Kesehatan Republik Indonesia, 2017). The limits of this biologic parameter are $50 \mathrm{MPN} / 100 \mathrm{~mL}$ for Total Coliforms and $0 \mathrm{CFU} / 100 \mathrm{~mL}$ for $E$. Coli bacteria. The types of manholes which were being analyzed in this research is shown in Table 2 as below.

Table 2. Manhole Types

\begin{tabular}{lll}
\hline No. & Picture of Manhole & Description \\
\hline 1. & $\begin{array}{l}\text { Precast concrete type } \\
\text { manhole }\end{array}$ & Masonry type manhole \\
2. & & $\begin{array}{l}\text { Ring type precast } \\
\text { concrete manhole }\end{array}$ \\
3. & & $\begin{array}{l}\text { Cast-in-situ concrete } \\
\text { manhole }\end{array}$ \\
\end{tabular}

2.3. Wastewater Discharge Measurement and Wastewater Quality Assessment

This research has focused on the technical performance of the DWWTP in accordance with Permen PUPR No.04 Tahun 2017 (Peraturan Menteri Pekerjaan Umum dan Perumahan Rakyat,
2017) to evaluate the influent discharge of wastewater, capacity of the DWWTP and the quality of wastewater treatment effluent. Influent of wastewater discharge at the DWWTP has been determined from the mean daily discharge using the formula below (Crites \& Tchobanoglous, 1998), adapted and converted to SI units:

$Q=\frac{V}{t}$

Where, $Q$ is discharge in cubic metre per day $\left(\mathrm{m}^{3} / \mathrm{d}\right), V$ is daily wastewater volume in cubic metre, and $t$ is time in days.

In this research, the influent discharge measurement was conducted since 6:00 a.m. Western Indonesian Time (WIB) until 6:00 p.m. WIB. Each period lasted for an hour of 5 measurements with total of 12 periods. The capacity parameter of the DWWTP is the capability of the DWWTP to serve the community at the design discharge. The total daily volume of wastewater for DWWTP type 1 was designed 35.64 cubic metres to 40.5 cubic metres for its 450 inhabitants while the total daily volume of wastewater for DWWTP type 2 was 36 cubic metres for its 400 inhabitants. $\mathrm{pH}$ is an important parameter in water and wastewater engineering (Shu et al., 2016), therefore it is measured. The measurement of $\mathrm{pH}$ in field was by digital $\mathrm{pH}$ meter while the method of the water quality analysis was by the Standard Methods. Wastewater quality of the effluent was evaluated according to Permen $L H K$ No. P.68 Tahun 2016 (Peraturan Menteri Lingkungan Hidup, 2016) and Perda DIY No.7 Tahun 2016 (Peraturan Daerah Daerah Istimewa Yogyakarta, 2016). Wastewater quality standard is the limit of pollution from a certain kind of pollutant that can be tolerated to be discharged to the nearest water body. The parameters which were tested and evaluated in compliance with the above standards were $\mathrm{pH}$, Temperature, $\mathrm{BOD}_{5}$ (Biochemical Oxygen Demand on the $5^{\text {th }}$ day) which will be abbreviated as $\mathrm{BOD}_{5}$, COD (Chemical Oxygen Demand), TSS (Total Suspended Solids), TDS (Total Dissolved Solids), Oil and Grease, Total Coliforms, Ammonia and 
Detergent. At the DWWTP type 1 which owned a Chlorination chamber, Chlorine concentration of the effluent was also being measured to evaluate whether it is tolerable at the concentration of $0.2 \mathrm{mg} / \mathrm{L}$ or less (Saraswati, 1996). Removal efficiency of the wastewater quality treatment was calculated with the universal formula for $\mathrm{BOD}_{5}, \mathrm{COD}$, TSS, TDS, Ammonia, Oil and Grease, Detergent and Total Coliforms as below:

Removal Efficiency =

$\left(\frac{\text { Inlet concentration-Outlet concentration }}{\text { Inlet concentration }}\right) \times 100 \%$

Flow rate or discharge which flowed into the system was stated as feasible when the discharge was less or equal to the design discharge, and so was the capacity. Method used to judge the feasibility of the wastewater quality effluent was the result of the parameters above compared to the wastewater quality standards. In addition to the method above, Pollution Index (PI) was also used to rate the effluent parameters.

\subsection{Pollution Index}

In this research, Pollution Index Method (PI) by Nemerow \& Sumitomo (1970) was used. This index is used to show a relative term of the permissible pollution level.

$P I_{j}=\frac{\sqrt{\left(\frac{c_{i}}{L_{i j}}\right)^{2} \operatorname{Max}+\left(\frac{c_{i}}{L_{i j}}\right)^{2} \text { Mean }}}{2}$

Where, $P I$ is pollution index for $\mathrm{j}$ purpose or the use $j, C_{i}$ is multiple items of water quality parameters, $\mathrm{L}_{\mathrm{ij}}$ is permissible levels of the perspective items for a use.

In this research, the evaluation of pollution levels compared to PI is as below:

$0 \leqslant P I_{j} \leqslant 1.0$ good condition

$1.0<P I_{j} \leqslant 5.0$ slightly polluted

$5.0<P I_{j} \leqslant 10$ moderately polluted

$P I_{j}>10$ highly polluted

with $P I_{j}$ is pollution index for $j$ purpose abbreviated as PI

\section{RESULTS}

\subsection{Wastewater Discharge and Capacity}

Figure 3 and Figure 4 depict the influent discharge of DWWTP type 1 and DWWTP type 2 consecutively. While results of the detention time or retention time are shown in Table 3 for DWWTP type 1 and in Table 4 for DWWTP type 2. The calculated mean discharge line was found above the design discharge line for DWWTP type 1. Flow velocity or influent velocity $(v)$ which influenced the detention time $\left(t_{d}\right)$ was fast in DWWTP type 1 ; thus, it can be seen that in DWWTP type 1, the existing detention time was far too short, and the existing capacity exceeded the design capacity which made the wastewater treatment became not optimal with peak flow of $113.53 \mathrm{~m}^{3} / \mathrm{d}$. In DWWTP type 2, longer existing detention time of $\mathrm{ABR}$ and $\mathrm{AF}$ compared to that of the design detention time made the treatment plant worked optimal, with calculated mean discharge line found below the design discharge line with peak flow of $34.44 \mathrm{~m}^{3} / \mathrm{d}$.

Table 3. Measurement Results of Detention Time in DWWTP type 1

\section{A}

\begin{tabular}{|c|c|c|c|c|c|c|c|c|c|c|}
\hline Description & $\begin{array}{l}t_{d} \\
\text { (hour) }\end{array}$ & $\begin{array}{l}v \\
\text { (m/hour) }\end{array}$ & $\begin{array}{l}t_{d} \\
\text { (hour) }\end{array}$ & $\begin{array}{l}v \\
(\max 0.5 \\
\mathrm{m} / \text { hour })\end{array}$ & $\begin{array}{l}t_{d} \\
\text { (hour) }\end{array}$ & $\begin{array}{l}v \\
(\max \\
2 \mathrm{~m} / \text { hour})\end{array}$ & $\begin{array}{l}t_{d} \\
\text { (hour) }\end{array}$ & $\begin{array}{l}v \\
\text { (m/hour) }\end{array}$ & $\begin{array}{l}t_{d} \\
\text { (hour) }\end{array}$ & $\begin{array}{l}v \\
\text { (m/hour) }\end{array}$ \\
\hline Design & $1 / 6$ & 2.68 & 12 & 0.167 & 12 & 1.24 & 3 & 13.41 & 0.5 & 2.24 \\
\hline Existing & 0.02 & 8.51 & 3.78 & 0.53 & 1.01 & 3.94 & 0.95 & 42.57 & 0.16 & 7.09 \\
\hline
\end{tabular}

Note: $\mathrm{A}$ = Equalization Tank; $\mathrm{B}=$ Settler; $\mathrm{C}$ = Anaerobic Filter; $\mathrm{D}=$ Horizontal Gravel Filter; E = Chlorination Chamber; deposition time in this paper is written as $t_{d} . v=$ flow velocity 
Table 4. Measurement Results of Detention Time in DWWTP type 2

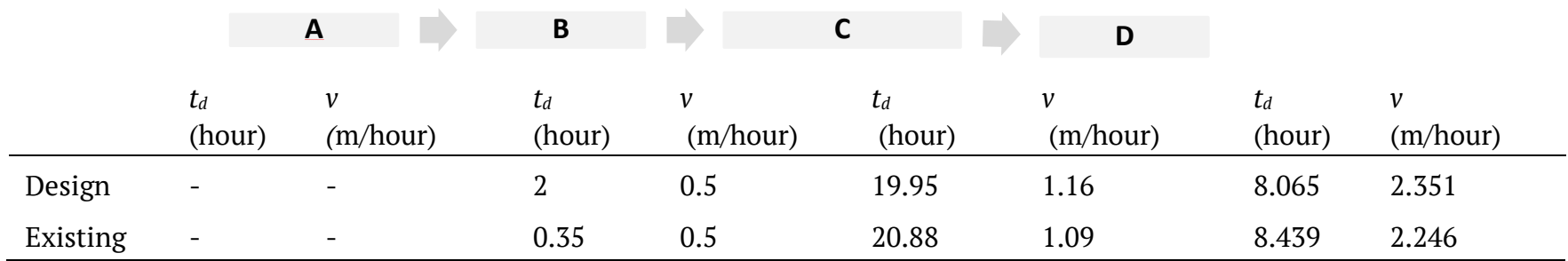

Note: A= Equalization Tank; $B=$ Settler C = Anaerobic Baffled Reactor; $D=$ Anaerobic Filter, deposition time in this paper is written as $\mathrm{t}_{\mathrm{d}} . v=$ flow velocity

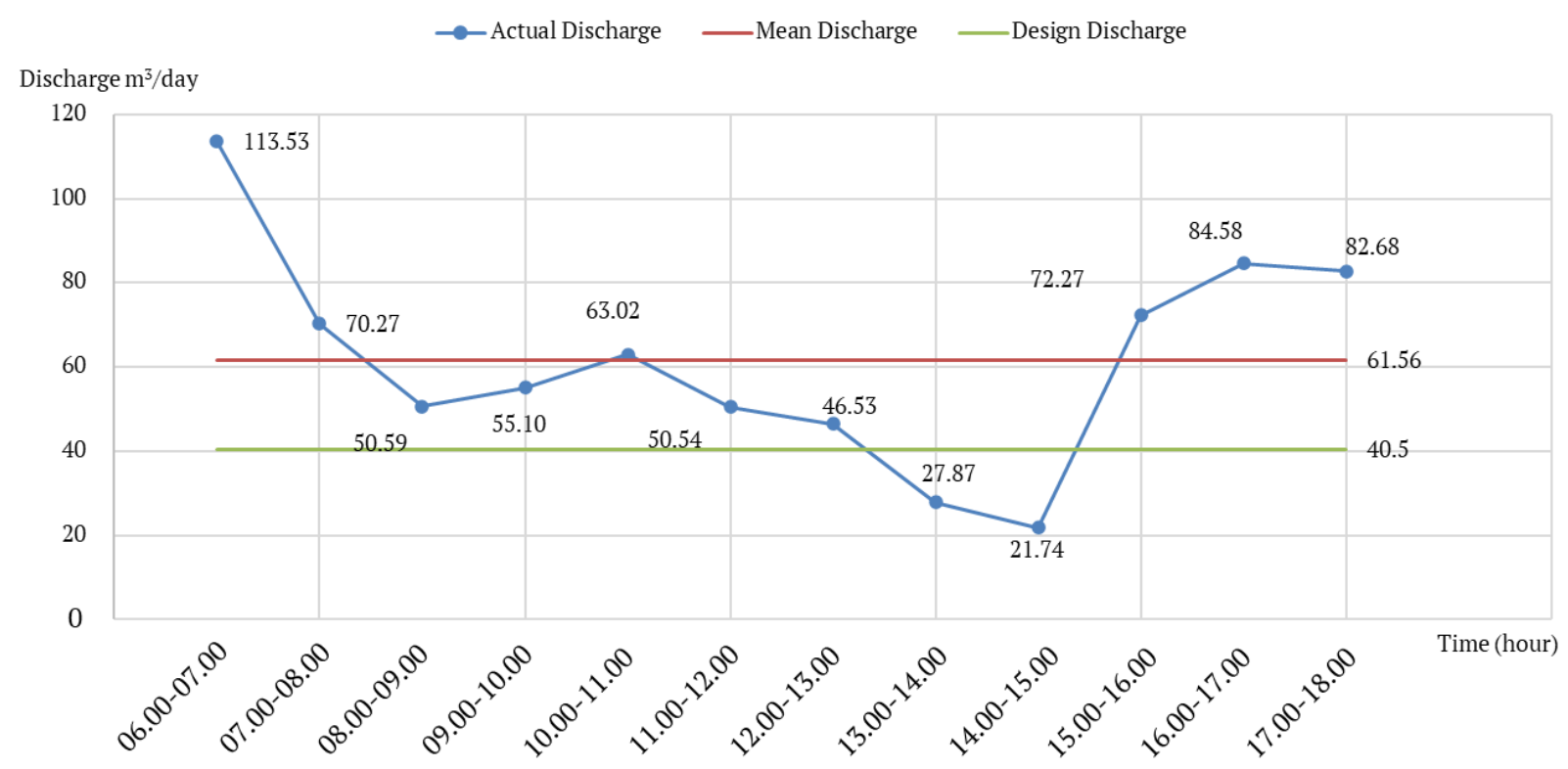

Figure 3. Calculation Result Plot of Discharge for DWWTP type 1. Discharge performance of the influent at the inlet of DWWTP type 1 with mean discharge found above the design discharge.
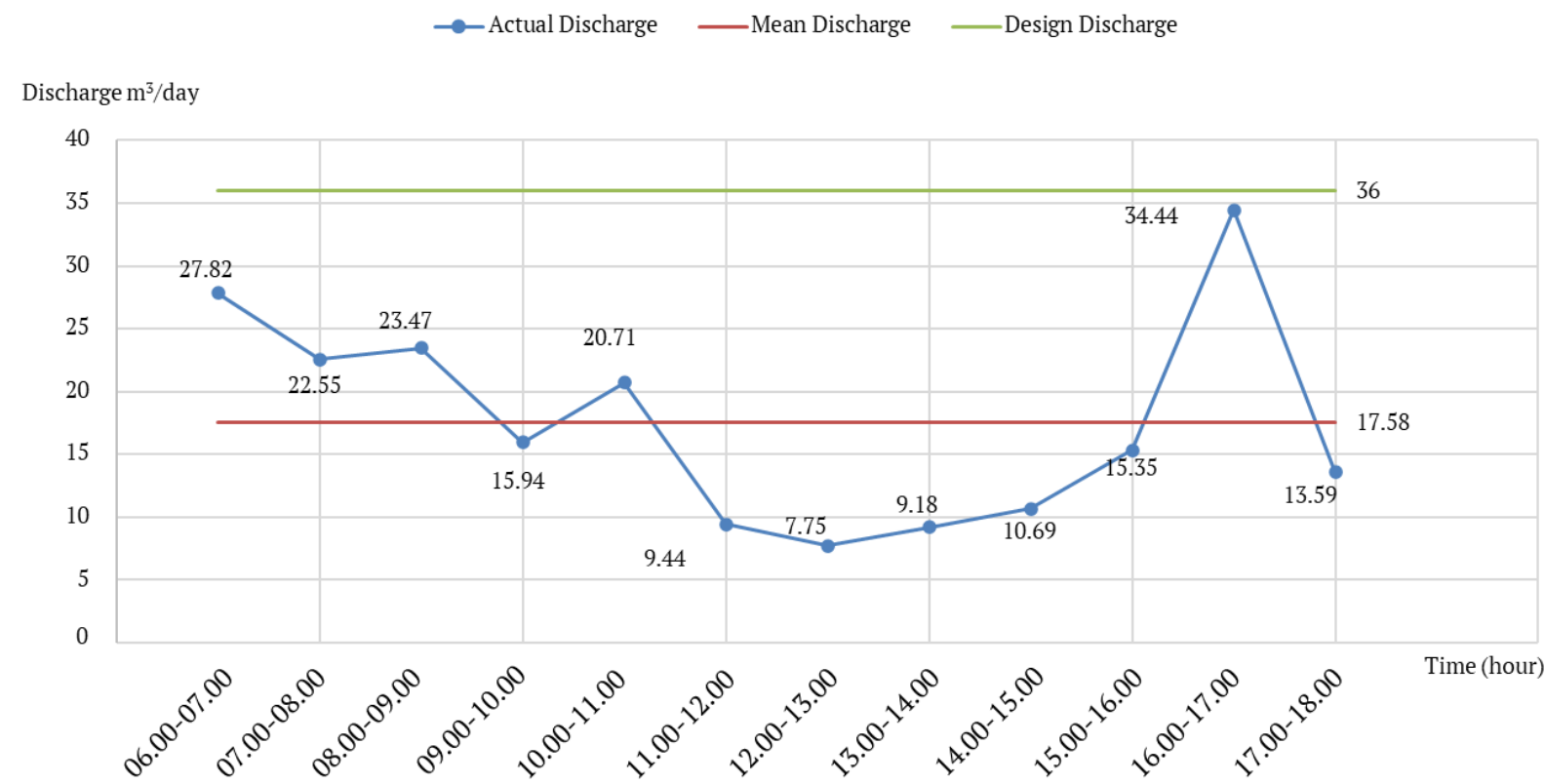

Figure 4. Calculation Result Plot of Discharge for DWWTP type 2. Discharge performance of the influent at the inlet of DWWTP type 2 with mean discharge found below the design discharge. 


\subsection{Wastewater Treatment Quality Results}

Eleven parameters of wastewater quality (including Chlorine concentration) for the effluent of the DWWTP type 1 has been analyzed in comparison to the Domestic Wastewater Quality Standards in the Indonesian legal regulation as well as 10 parameters (without Chlorine concentration) of the DWWTP type 2 . The results are as shown in Table 5 and Table 6.

Table 5. Wastewater Quality of DWWTP type 1

\begin{tabular}{|c|c|c|c|c|c|c|}
\hline Parameter & Unit & $\begin{array}{l}\text { Permissible } \\
\text { Quality } \\
\text { Standard }\end{array}$ & Influent & Effluent & $\begin{array}{l}\text { Removal } \\
\text { Efficiency } \\
(\%)\end{array}$ & $\begin{array}{l}\text { Wastewater } \\
\text { Quality Effluent } \\
\text { Conclusion }\end{array}$ \\
\hline Temperature $* * *$ & ${ }^{\circ} \mathrm{C}$ & $24.5-27.5$ & 27.97 & 28.30 & - & NA \\
\hline $\mathrm{pH}^{*}$ & - & $6-9$ & 7.24 & 7.06 & - & A \\
\hline $\mathrm{TDS}^{* * *}$ & $\mathrm{mg} / \mathrm{L}$ & 2000 & 164.33 & 179.33 & 0 & $\mathrm{~A}$ \\
\hline TSS* & $\mathrm{mg} / \mathrm{L}$ & 30 & 72.33 & 15.33 & 78.81 & $\mathrm{~A}$ \\
\hline $\mathrm{BOD}_{5} *$ & $\mathrm{mg} / \mathrm{L}$ & 30 & 202.95 & 106.72 & 47.42 & NA \\
\hline $\mathrm{COD}^{*}$ & $\mathrm{mg} / \mathrm{L}$ & 100 & 377.60 & 247.59 & 34.43 & NA \\
\hline Ammonia* & $\mathrm{mg} / \mathrm{L}$ & 10 & 36.50 & 40.50 & 0 & NA \\
\hline Detergent ${ }^{* * *}$ & $\mathrm{mg} / \mathrm{L}$ & 5 & 13.75 & 9.18 & 33.21 & NA \\
\hline Oil and Grease* & $\mathrm{mg} / \mathrm{L}$ & 5 & 12.67 & 5.00 & 60.54 & A \\
\hline Total Coliforms* & MPN/100 mL & 3000 & $>1.600 \times 10^{5}$ & $>1.600 \times 10^{5}$ & 0 & NA \\
\hline Chlorine residue ${ }^{* * * *}$ & $\mathrm{mg} / \mathrm{L}$ & 0.2 & - & $<0.001$ & - & $\mathrm{A}$ \\
\hline
\end{tabular}

*) Permen LHK No.P.68 Tahun 2016; **) Perda DIY No.7 Tahun 2016; ***) Saraswati, 1996; A=Appropriate; NA=Not Appropriate. Note: removal efficiency is written 0 for TDS and Ammonia since there were increment at the outlet.

Table 6. Wastewater Quality of DWWTP type 2

\begin{tabular}{|c|c|c|c|c|c|c|}
\hline Parameter & Unit & $\begin{array}{l}\text { Permissible } \\
\text { Quality } \\
\text { Standard }\end{array}$ & Influent & Effluent & $\begin{array}{l}\text { Removal } \\
\text { Efficiency } \\
(\%)\end{array}$ & $\begin{array}{l}\text { Wastewater } \\
\text { Quality Effluent } \\
\text { Conclusion }\end{array}$ \\
\hline Temperature ${ }^{* * *}$ & ${ }^{\circ} \mathrm{C}$ & $24.5-27.5$ & 27.63 & 27.97 & - & NA \\
\hline $\mathrm{pH}^{*}$ & - & $6-9$ & 7.47 & 7.07 & - & A \\
\hline TDS*** & $\mathrm{mg} / \mathrm{L}$ & 2000 & 126.67 & 117.67 & 7.11 & A \\
\hline TSS* & $\mathrm{mg} / \mathrm{L}$ & 30 & 29 & 20.90 & 27.93 & A \\
\hline $\mathrm{BOD}_{5}^{*}$ & $\mathrm{mg} / \mathrm{L}$ & 30 & 136.65 & 54.94 & 59.80 & NA \\
\hline $\mathrm{COD}^{*}$ & $\mathrm{mg} / \mathrm{L}$ & 100 & 314.73 & 84.22 & 73.24 & A \\
\hline Ammonia* & $\mathrm{mg} / \mathrm{L}$ & 10 & 34 & 27.00 & 20.59 & NA \\
\hline Detergent $^{* * *}$ & $\mathrm{mg} / \mathrm{L}$ & 5 & 7.94 & 4.01 & 49.50 & A \\
\hline Oil and Grease* & $\mathrm{mg} / \mathrm{L}$ & 5 & 17 & 4.67 & 72.53 & A \\
\hline Total Coliforms* & MPN/100mL & 3000 & $\begin{array}{l}>1.600 \mathrm{x} \\
10^{5}\end{array}$ & $\begin{array}{l}>1.600 \times \\
10^{5}\end{array}$ & 0 & NA \\
\hline
\end{tabular}

*) Permen LHK No.P.68 Tahun 2016; **) Perda DIY No.7 Tahun 2016; A=Appropriate; NA=Not Appropriate 
The results showed that wastewater treatment quality effluent parameters which met the Indonesian legal regulation were $\mathrm{pH}$, TSS, TDS, Oil and Grease and Chlorine for DWWTP type 1. COD reduction efficiency of DWWTP type 1 was less than 50\%, while DWWTP type 2 COD reduction was $73.24 \%$. There was no effective reduction of Ammonia concentration in both types of DWWTP.

Parameters of the effluent which met the Indonesian legal regulation were $\mathrm{pH}$, TSS, TDS, Oil and Grease, Detergent and COD for DWWTP type 2. The Pollution Index (PI) of DWWTP type 1 effluent was found higher than the PI of DWWTP type 2 as shown in Figure 5, although both were at the moderately polluted level. There are several methods in wastewater quality assessment (Saraswati et al., 2014), yet PI is the most reliable method for describing wastewater quality from instantaneous effluent.

\subsection{E. Coli Presence Under Manholes}

Groundwater quality near to the manholes in the research area had been measured for Total Coliforms parameter to know the possibility of bacterial leaching from the manholes nearby.
Secondary data showed that Total Coliforms of Bapak Haryanto's groundwater well was 1600MPN/100mL while Bapak Yulianto's was 79 MPN/100mL (Diavid et al., 2018). These results showed that there were possibilities of leaching from nearby wastewater system. Therefore the $E$. Coli bacteria in soils under the manholes were being analyzed to know which types of manholes gave the least bacteria leaching to the ground. The results in Table 7 shows that the $E$. Coli bacteria was not present only in soils under the ring type precast concrete manholes.

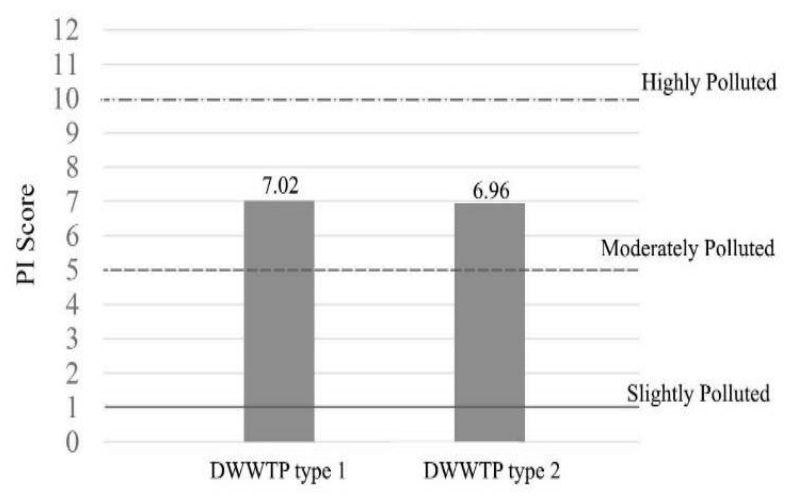

Figure 5. Pollution Index Chart. PI of DWWTP type 1 is 7.02 that is higher than that of DWWTP type 2 which is 6.96. Both are in the range of moderately polluted level

Table 7. Total Coliforms and E.Coli Bacteria in Soils Under Manholes

\begin{tabular}{|c|c|c|c|c|c|}
\hline $\begin{array}{l}\text { Location of } \\
\text { DWWTP and } \\
\text { Manhole }\end{array}$ & Manhole Types & $\begin{array}{l}\text { Total Coliforms } \\
\text { (MPN/100mL) }\end{array}$ & $\begin{array}{l}\text { Permissible } \\
\text { Quality } \\
\text { Standard of } \\
\text { Total Coliforms } \\
\text { (MPN/100mL)* }\end{array}$ & $\begin{array}{l}\text { E. Coli } \\
(\mathrm{cfu} / 100 \mathrm{~mL})\end{array}$ & $\begin{array}{l}\text { Permissible } \\
\text { Quality } \\
\text { Standard of } E \text {. } \\
\text { Coli } \\
(\mathrm{cfu} / 100 \mathrm{~mL})^{*}\end{array}$ \\
\hline
\end{tabular}

\begin{tabular}{|c|c|c|c|c|c|}
\hline \multicolumn{6}{|c|}{ Manholes which are connected to pipes prior to entering DWWTP type 1: } \\
\hline M1S1 & precast concrete & 204,440 & 50 & $>1.6 \times 10^{5}$ & np \\
\hline M1S2 & precast concrete & 359,100 & 50 & $>1.6 \times 10^{5}$ & np \\
\hline M1S3 & precast concrete & $5,130,000$ & 50 & $>1.6 \times 10^{5}$ & np \\
\hline \multicolumn{6}{|c|}{ Manholes which are connected to pipes prior to entering DWWTP type 2: } \\
\hline M2S1 & masonry & $1,170,400$ & 50 & $1.12 \times 10^{5}$ & np \\
\hline M2S2 & masonry & $48,260,000$ & 50 & $>1.6 \times 10^{5}$ & np \\
\hline M2S3 & masonry & $2,196,400$ & 50 & $>1.6 \times 10^{5}$ & np \\
\hline \multicolumn{6}{|c|}{ Two other samples of common manhole types in Sleman Regency: } \\
\hline M3S1 & ring type precast concrete & 95,350 & 50 & $\mathrm{np}$ & np \\
\hline M3S2 & ring type precast concrete & 17,784 & 50 & $\mathrm{np}$ & np \\
\hline M3S3 & masonry & 118,560 & 50 & $1.19 \times 10^{5}$ & np \\
\hline M4S1 & cast-in-situ concrete & 657,400 & 50 & $>1.6 \times 10^{5}$ & np \\
\hline M4S2 & cast-in-situ concrete & 184,680 & 50 & $>1.6 \times 10^{5}$ & np \\
\hline M4S3 & cast-in-situ concrete & 62,320 & 50 & $0.97 \times 10^{5}$ & np \\
\hline
\end{tabular}

Notes: *) Permenkes No. 32 Tahun 2017; np= not present (negative result in plating or $=0 \mathrm{cfu} / 100 \mathrm{~mL}$ ) 


\section{DISCUSSION}

\subsection{Wastewater Treatment Quality and E. Coli Presence Under Manholes}

It could be seen from Table 5 and 6 that TSS and TDS of the effluent for both DWWTP type 1 and DWWTP type 2 were appropriate, although there was an increase of TDS in DWWTP type 1. The increase of TDS could happen in an anaerobic treatment plant when the TSS with larger particle size has decreased in the degradation process to contribute to the increment of TDS and this smaller dissolved particle has not been fully degraded into gas (Susanthi et al., 2018). In DWWTP type 1, COD of the effluent was found not appropriate. The high COD indicated that the microorganism process in the system was not effective; this phenomenon could happen when the microorganism is not fully degraded, or when the detention time is too short which caused an inefficient degradation process (Susanthi et al., 2018).

In DWWTP type 2, the COD effluent was appropriate according to the Indonesian legal regulation that is below $100 \mathrm{mg} / \mathrm{L}$, in conjunction with longer detention time. Both $\mathrm{BOD}_{5}$ effluents were found not appropriate according to the Indonesian legal regulation for DWWTP type 1 and type 2; yet the efficiency of reduction was higher in DWWTP type 2. The high $\mathrm{BOD}_{5}$ concentration in the effluent of treatment plants can be caused by the high organic matters from the influent which is not equipoised by an adequate treatment process or because of the high influent discharge (Sulihingtyas et al., 2010; Susanthi et al., 2018). Both DWWTP type 1 and type 2 effluents were not appropriate in term of Total Coliforms and Ammonia removal.

The high concentration of coliforms in the effluent of a treatment plant can be caused by the excreta sludge deposition at the outlet with no adequate sludge pumping or draining and maintenance which need continuous maintenance of at least once in every two years (Susanthi et al., 2018). The effluent of DWWTP type 1 was not appropriate in term of Detergent concentration while DWWTP type 2 was appropriate.

The detention time has a great role on the decrease of Detergent constituent (Amal, 2011). Amal (2011) has researched alum and dry clays 'ampo' which can be added to make a better efficiency of the Detergent reduction. It was concluded at a laboratory scale that $125 \mathrm{mg} / \mathrm{L}$ of alum and $2 \mathrm{~g} / \mathrm{L}$ of 'ampo' with detention time of 48 hours was the optimum dose for Detergent reduction with $41.6 \%$ efficiency. More parameters of the wastewater quality effluent were appropriate for DWWTP type 2 as shown in Table 5 and 6 which resulted on lower PI in Figure 5 for DWWTP type 2. E. Coli bacteria was not present only in soils under the ring type precast concrete manholes. Therefore, this type of infrastructure is recommended.

\subsection{Social Perspectives and Future Recommendations}

The study of Dwipayanti et al. (2019) revealed that cultural aspects in rural communities provide important insights for a sanitation program design and its implementation. In Sleman, where people are living mostly as a multicultural society of many educational and cultural backgrounds, surveys for the most acceptable wastewater treatment in the near future with some available alternatives proposed by the researchers are possible. The effluent of wastewater which passed the DWWTP could be upgraded in the future design for a better wastewater quality result.

A tertiary wastewater treatment can be recommended. After reaching water bodies, effluent of wastewater can be recollected for further research, both the quantity and the quality, such as the effluent to the nearby river or open channel because infiltration of open channel water to the aquifer is probable. Hauwert (2016) stated that the approach of channel water balance analysis can lead to the understanding of water sources for the aquifer, which is critical for focusing management efforts. The waste from the treated wastewater can also be reused. Producing non-reinforced concrete 
from treated domestic wastewater can be an alternative of using treated wastewater which was treated by septic tank followed by anaerobic filter and sand filter (Duarte et al., 2019). Full scale decentralized system has been researched in Brazil by de Oliveira Cruz et al. (2018) with septic tank and sand filter which were built with precast concrete rings. The quality of effluent met the legal aspects and the final effluent can be reused in agriculture activities with good maintenance frequency (de Oliveira Cruz et al., 2018).

Wastewater reuse for gardens or constructed wetlands in the peri-urban as well as in the city or urban area can be a great challenge in the future for communities in Sleman Regency. Structure and pattern of urban green space has a significant role for the landscape ecology, especially in a compact city with a limited space (Liang et al., 2017). Iribarnegaray et al. (2018) revealed that inclusion of DWWTS (Decentralized Wastewater Treatment Systems) in urban planning could reduce overall investment costs and the correct use of DWWTS could also allow a more secure scenario for effluent reuse. Cost effective innovative technology such as DMR (Domestic MultiRecycler) is needed to restore poor water pollution that poses serious health threat to people in developing countries and to improve the soundness of water and wastewater recycling system (Uzuh et al., 2019).

Marleni \& Raspati (2020) stated that wastewater contains many valuable resources that can be converted into valuable materials to generate various products such as energy and heat. Far before the twenty first century, waste of animals and nature had been researched in Uganda to produce biogas. This research evaluated the use of three different substrates: cow dung; straw from maize stalk and elephant grass; and a mixture of straw and cow dung, to produce a better biogas composition (Ilukor, 1986). Ilukor (1986) has also used the effluent from the biogas digester as a fertilizer and the gas was used for cooking, lamps, heaters and dryers. To date, researchers have been researching the use of human waste. Human faeces wastewater was researched by Fangzhou et al. (2011) to produce electricity.

On a design experiment scale, Nisa (2015) has researched the addition of bran for the production of biogas in the wastewater treatment plant. (Andriani et al., 2015) showed that the application of biogas using human excreta provided alternative energy source and helped the environment while sludge itself could be piped to the fish pond or further processed into fertilizer. The investment of private sector in wastewater management is also recommended. Low technology sanitation has largely been driven by complex economics, institutional as well as sociocultural factors, and efforts in the future to make a reform program would have to be accelerated by forging partnerships with the private sector to provide efficient and low cost resources for technologies, financial schemes, human and technical resources for improved service delivery (Appiah-Effah et al., 2019).

The obstacles in implementation of wastewater resources recovery which urged not only treatment but also utilization should be identified and the solution for an effective and new wastewater management blueprint must be constructed (Marleni \& Raspati, 2020). In Sleman Regency, some efforts have been started and in the near future, the engagement with private sectors for funding and technologies are encouraged.

\section{CONCLUSIONS}

This research evaluated two domestic wastewater plants in Sleman Regency, DIY, Indonesia; DWWTP type 1 in Sembir area and DWWTP type 2 in Tambakrejo area consecutively to give recommendation on a better construction design for wastewater treatment system in the near future. DWWTP type 1 influent discharge was larger than the design discharge which made the capacity not optimal for treating wastewater. Wastewater treatment quality effluent parameters which met the Indonesian legal regulation were $\mathrm{pH}$, TSS, TDS, Oil and Grease and Chlorine for 
DWWTP type 1; yet the Total Coliforms and Ammonia were still high. Optimization of the Chlorination chamber is needed. Other future process to alleviate the pollutant could be tertiary treatment prior to disinfection, such as adding a biogas digester with solid waste of bran to increase the production of methane or improved constructed wetlands when the land area is available and permissible. DWWTP type 2 influent discharge met the design discharge criteria with longer detention time or retention time. This design made more effluent of wastewater quality appropriate with lower PI than that of DWWTP type 1. Parameters of the effluent which met the Indonesian legal regulation were $\mathrm{pH}$, TSS, TDS, Oil and Grease, Detergent and COD. COD reduction for DWWTP type 2 was appropriate with a high efficiency of $73.24 \%$. Manhole material which is recommended for future use is the ring type precast concrete which made the $E$. Coli bacteria not present in soils under the manholes. Careful supervision is needed to make impervious grout lined section while making the manholes to eliminate wastewater leakage as well as good maintenance frequency of the manholes.

\section{DISCLAIMER}

The authors declare no conflict of interest.

\section{AVAILABILITY OF DATA AND MATERIALS}

All data are available from the authors.

\section{ACKNOWLEDGMENTS}

The authors would like to thank K.S.M. Sembir Asri and K.S.M. Tambakrejo Bersih for their field assistance. The authors would also like to acknowledge the service of Balai Laboratorium Kesehatan BBTKLPP, Yogyakarta (Centre of Public Health and Sanitation Laboratory, Yogyakarta), Laboratorium Mikrobiologi Pertanian, Fakultas Pertanian, UGM (Microbiology Laboratory, Faculty of Agriculture, UGM) and Balai PIPBPJK, Sleman, Yogyakarta (Centre for Building Testing, Information and Construction Development, Sleman, Yogyakarta) for the wastewater and soil quality testing in the laboratory.

\section{REFERENCES}

Amal, N., 2011. Usaha Peningkatan Kualitas Air dengan Variasi Penambahan Tawas- Lempung Kering 'Ampo' pada Limbah Domestik yang Mengandung Deterjen (Efforts to Improve Water Quality by Adding Variations of Alum and Dry Clays 'Ampo' on Domestic Wastewater Containing Detergent). Info Teknik, 12(2), pp. 40-47.

Andriani, D., Wresta, A., Saepudin, A. \& Prawara, B., 2015. A Review of Recycling of Human Excreta to Energy through Biogas Generation: Indonesian Case. Energy Procedia, 68, pp. 219225.

Appiah-Effah, E., Duku, G.A., Azangbego, N.Y., Aggrey, R.K.A., Gyapong-Korsah, B. \& Nyarko, K.B., 2019. Ghana's Post-MDG Sanitation Situation: An Overview. Journal of Water, Sanitation and Hygiene for Development, 9(3), pp. 397-415.

Asmadi \& Suharno, 2012. Dasar-Dasar Teknologi Pengelolaan Air Limbah (Fundamentals of Wastewater Treatment Technology). Yogyakarta: Gosyen Publishing.

Asriningtyas, V. \& Putra, D.P.E., 2006. Ten Year Groundwater Simulation in Merapi Aquifer, Sleman, DIY, Indonesia. Indonesian Journal of Geography, 38(1), pp. 1-14.

Crites, R. \& Tchobanoglous, G., 1998. Small and Decentralized Wastewater Management Systems. New York: McGraw-Hill Company Inc.

De Oliveira-Cruz, L.M., Tonetti, A.L. \& Gomes, B.G.L.A., 2018. Association of Septic Tank and Sand Filter for Wastewater Treatment: Full-Scale Feasibility for Decentralized Sanitation. Journal of Water, Sanitation and Hygiene for Development, 8(2), pp. 268-277.

Duarte, N.C., dos Santos Amaral, A.E., Gomes, B.G.L.A., Siqueira, G.H. \& Tonetti, A.L., 2019. Water Reuse in the Production of NonReinforced Concrete Elements: An Alternative for Decentralized Wastewater Management. 
Journal of Water, Sanitation and Hygiene for Development, 9(3), pp. 596-600.

Diavid, G.H., Saraswati, S.P. \& Nugroho, A.S.B, 2018. Evaluasi Kelayakan Kinerja Sistem Instalasi Pengolah Air Limbah Domestik: Studi Kasus di Kabupaten Sleman (Feasibility Evaluation of Domestic Wastewater Installation System: A Case Study in Sleman Regency). Malang, Prosiding SNTT Politeknik Negeri Malang.

Dwipayanti, N.M.U., Rutherford, S. \& Chu, C., 2019. Cultural Determinants of Sanitation Uptake and Sustainability: Local Values and Traditional Roles in Rural Bali, Indonesia. Journal of Water, Sanitation and Hygiene for Development, 9(3), pp. 438-449.

Fangzhou, D., Zhengdong, L., Shaoqiang, Y., Beizhen, X.\& Hong, L., 2011. Electricity Generation Directly Using Human Feces Wastewater for Life Support System. Acta Astronautica, 68(9-10), pp. 1537-1547.

Foggitt, E., Cawood, S., Evans, B. \& Acheampong, P., 2019. Experiences of Shared SanitationTowards a Better Understanding of Access, Exclusion and "Toilet Mobility" in Low-Income Urban Areas. Journal of Water, Sanitation and Hygiene for Development, 9(3), pp. 581-590.

Hauwert, N.M., 2016. Stream Recharge Water Balance for the Barton Springs Segment of the Edwards Aquifer. Journal of Contemporary Water Research and Education, 159(1), pp. 24-49.

Hibbs, B., Harrison, M. \& Merino, M., 2016. Issues of Stream-Aquifer Interactions in Grout Lined Channels in Urban Watersheds. Journal of Contemporary Water Research and Education, 159(1), pp. 127-143.

Ilukor, J. 1986 Uganda Biogas Project. In: ElHalwagi M.M. (eds.) Biogas Technology, Transfer and Diffusion, Springer, Dordrecht. https://doi.org/10.1007/978-94-009-4313-1_79

Iribarnegaray, M.A., Rodriguez-Alvarez, M.S., Morana, B., Tejerina, W.A. \& Seghezzo, L., 2018. Management Challenges for a More
Decentralized Treatment and Reuse of Domestic Wastewater in Metropolitan Areas. Journal of Water, Sanitation and Hygiene for Development, 8(1), pp. 113-122.

Liang, H., Chen, D. \& Zhang, Q., 2017. Assessing Urban Green Space Distribution in a Compact Megacity by Landscape Metrics. Journal of Environmental Engineering and Landscape Management, 25(1), pp. 64-74. https://doi.org/10.3846/16486897.2016.1210157

Manny, L., Atmaja, R.R.S. \& Putra, D.P.E., 2016. Groundwater Level Changes in Shallow Aquifer of Yogyakarta City, Indonesia: Distribution and Causes. Journal of Applied Geology, 1(2), pp. 8999.

Marleni, N.N.N. \& Raspati, G.S., 2020. A Critical Review of Wastewater Resources Recovery Implementation in Indonesia. JCEF, 6(1), pp. 89102.

Meynendonckx, J., Heuvelmans, G., Muys, B. \& Feyen, C., 2006. Effects of Watershed and Riparian Zone Characteristics in the River Scheldt Basin. Hydrol.Earth.Syst.Sci., 10(6), pp. 913-922.

Nemerow, N.L. \& Sumitomo, H., 1970. Report No. 16110 DAJ - Benefits of Water Quality Enhancement, Syracuse, N.Y.: Prepared for The U.S. Environmental Protection Agency.

Nisa, S.A., 2015. Perancangan Ulang Desain Septic Tank berdasarkan Pengaruh Penambahan 6\% Bekatul terhadap Produksi Biogas dan Efisiensi Removal Air Limbah pada Septic Tank Digester (Studi Kasus Bulaksumur Residence) (Redesign of Septic Tank Based on the Impact of 6\% Bran Addition to Biogas Production and Wastewater Removal Efficiency on Septic Tank Digester (Case Study of Bulaksumur Residence)). Yogyakarta: Bachelor Thesis Report. Department of Civil and Environmental Engineering. Universitas Gadjah Mada.

Peraturan Menteri Kesehatan Republik Indonesia No. 32 Tahun 2017 tentang Standar Baku Mutu Kesehatan Lingkungan dan Persyaratan Kesehatan Air untuk Keperluan 
Higiene, Sanitasi, Kolam Renang, Solus Per Aqua, dan Pemandian Umum (Minister of Health Regulation, Republic of Indonesia No. 32/2017 on Environmental Health Quality Standards and Water Health Requirements for Sanitation and Hygiene, Swimming Pool, Solus per Aqua and Community Bath), Jakarta: Kementrian Kesehatan RI.

Peraturan Menteri Pekerjaan Umum dan Perumahan Rakyat No. 04/PRT/M/2017, tentang Penyelenggaraan Sistem Pengelolaan Air Limbah Domestik (Regulation of Minister of Public Works and Public Housing No. 04/PRT/M/2017 on Implementation of Domestic Wastewater Management System), Jakarta: Kementrian PUPR RI.

Peraturan Menteri Lingkungan Hidup dan Kehutanan Republik Indonesia No. P.68/Menlhk/Setjen/Kum.1/8/2016 tentang Baku Mutu Limbah Domestik, Kementrian Lingkungan Hidup dan Kehutanan (Minister of the Environment and Forestry Regulation No. P.68/Menlhk/Setjen/Kum.1/8/2016 on Domestic Wastewater Quality Standards), Jakarta: Kementrian LH RI.

Peraturan Daerah Daerah Istimewa Yogyakarta No. 7 Tahun 2016 tentang Baku Mutu Air Limbah (Special Region of Yogyakarta Regional Regulation No. 7/2016 on Wastewater Quality Standards), Yogyakarta: Pemda DIY.

Reynaud, N.S., 2014. Operation of Decentralised Wastewater Treatment Systems (DEWATS) UnderTropical Field Conditions. Dresden: Dissertation Report, Faculty of Environmental Sciences, Technical University.

Saraswati, S.P., 1996. Report of Environmental Health and Sanitation Engineering Laboratory Unit Proses Limbah Domestik (Domestic Waste Process Unit), Yogyakarta: Civil Engineering Department, Universitas Gadjah Mada.

Saraswati, S.P., Sunjoto, Kironoto, B.A. \& Hadisusanto, S., 2014. Kajian Bentuk dan Sensitivitas Rumus Indeks PI, Storet, CCME untuk Penentuan Status Mutu Perairan Sungai
Tropis di Indonesia (Assessment of the Forms and Sensitivity of the Index Formula PI, Storet, CCME for The Determination of Water Quality Status). J. Manusia dan Lingkungan, 21(2), pp. 129-142.

Saraswati, S.P., Ardion, M.V., Widodo, Y.H., Hadisusanto, S., 2019. Water Quality Index Performance for River Pollution Control Based on Better Ecological Point of View (A Case Study in Code, Winongo, Gadjah Wong Streams). JCEF, 5(1), pp. 47-55.

Sasse, L., 1998. Decentralized Wastewater Treatment in Developing Countries. Bremen: BORDA.

Satapona, A., Putra, D.P.E. \& Hendrayana, H., 2018. Groundwater Flow Modeling in The Malioboro, Yogyakarta, Indonesia. Journal of Applied Geology, 3(1), pp. 11-22.

Sembir Asri, K.S.M., 2017. Report of Sanimas Laporan Pelaksanaan Program Sanimas Pembangunan IPALD Skala Permukiman dengan Perpipaan (IPALD Sanimas Development Programme at Settlement Scale with Piping), Yogyakarta: Sanimas.

Shu, L., Obagbemi, I.J., Liyaanarachchi, S., Navaratna, D., Parthasarathy, R., Aim, R.B., Jegatheesan, V., 2016. Why does pH Increase with $\mathrm{CaCl}_{2}$ as Draw Solution during Forward Osmosis Filtration. Process Safety and Environmental Protection, 104, pp. 465-431.

Sulihingtyas, W.D., Suyasa, I.W.B. \& Wahyuni, N.M.I., 2010. Efektivitas Sistem Pengolahan Instalasi Pengolahan Air Limbah Suwung Denpasar terhadap Kadar BOD, COD, dan Amonia (The Effectiveness of the Suwung Denpasar Wastewater Treatment System on the Levels of BOD, COD and Ammonia). Journal of Chemistry, 4(2), pp. 141-148.

Susanthi, D., Purwanto, M.Y.J. \& Suprihatin, 2018. Evaluasi Pengolahan Air Limbah Domestik dengan IPAL Komunal di Kota Bogor (Evaluation of Domestic Wastewater Treatment Using Communal WWTP in Bogor City). Jurnal Teknologi Lingkungan, 19(2), pp. 229-238. 
Tambakrejo Bersih, K.S.M., 2012. Report Rencana Kerja Masyarakat Program USRI (USRI People Task Plan), Yogyakarta: USRI.

Uzuh, F.D., Toyoda, H. \& Matsubara, S., 2019.
Innovation for New Anaerobic Domestic Wastewater Treatment Recycling System in Developing Countries. Int. J. Water Wastewater Treat, 5(1), pp. 1-8. DOI: 10.16966/23815299.159 